\title{
Nutrient variations in the Sava River Basin
}

\author{
Janja Vrzel $^{1,2} \cdot$ Nives Ogrinc ${ }^{2,3}$
}

Received: 1 September 2014 / Accepted: 21 June 2015 /Published online: 3 July 2015

(C) The Author(s) 2015. This article is published with open access at Springerlink.com

\begin{abstract}
Purpose The first comprehensive evaluation and trend analysis of long-term nitrogen $(\mathrm{N})$ and phosphorus $(\mathrm{P})$ data was performed for the Sava River Basin (SRB) at locations in Slovenia, Croatia, and Serbia.

Materials and methods Data on long-term water quality at eight selected locations were evaluated statistically based on the period of reporting, availability of flow data, and the experience from our previous investigations. Trends in $\mathrm{NO}_{3}{ }^{-}$ and $\mathrm{PO}_{4}{ }^{3-}$ concentrations at locations were identified using simple linear regressions on log-transformed data.

Results and discussion Analysis indicated spatial and seasonal variability between locations. The highest long-term annual mean $\mathrm{NO}_{3}{ }^{-}$and $\mathrm{PO}_{4}{ }^{3-}$ concentrations were observed in Croatia and Serbia at locations that are susceptible to anthropogenic nutrient loading arising from high human population densities and intensive agricultural land use. Temporal variations indicate that river flow plays an important role in the distribution of $\mathrm{NO}_{3}{ }^{-}$and $\mathrm{PO}_{4}{ }^{3-}$ concentrations. Low flow during the summer months promotes reductive conditions leading to a minimum in annual mean $\mathrm{NO}_{3}{ }^{-}$concentrations and a maximum in annual mean $\mathrm{PO}_{4}{ }^{3-}$ concentrations resulting from the release of inorganic $\mathrm{P}$ from sediments. The highest annual mean $\mathrm{NO}_{3}{ }^{-}$concentrations were observed
\end{abstract}

Responsible editor: Fred Ellery

Nives Ogrinc

nives.ogrinc@ijs.si

1 Ecological Engineering Institute, Ltd, Maribor, Slovenia

2 Jožef Stefan International Postgraduate School, Ljubljana, Slovenia

3 Department of Environmental Sciences, Jožef Stefan Institute, Jamova 39, 1000 Ljubljana, Slovenia in winter/autumn under higher flow conditions that leach $\mathrm{NO}_{3}{ }^{-}$from soil and banks into the river. The results of trend analysis show a reduction of nutrients at the majority of locations ranging from 8 to $58 \%$.

Conclusions Although trends in $\mathrm{NO}_{3}{ }^{-}$and $\mathrm{PO}_{4}{ }^{3-}$ concentrations indicate a decrease at the majority of selected locations, it is still necessary to apply appropriate removal technologies in order to reduce the nutrient loads into the Sava River Basin and thereby improve water quality.

Keywords Computational methods · Nutrients · Sava River Basin · Statistics

\section{Introduction}

Nutrient enrichment or eutrophication is one of the important water quality issues limiting present and future uses of water resources. Although nutrients - mainly nitrogen $(\mathrm{N})$ and phosphorus $(\mathrm{P})$ - are necessary for the growth and survival of animals, plants, and other organisms, human activities have enhanced their global cycles by, on average, 100 and $400 \%$, respectively (Falkowski et al. 2000). Nutrient loads operate through both point and diffuse pathways linking land to water and are dependent on hydrology and in-stream processes such as transformation, retention, and elimination. Their concentrations and flux can vary significantly at different parts of the river in a manner related to short-term variations in hydrology and long-term changes of land use (Billen et al. 2007). Knowledge of mechanisms influencing the distribution of nutrients and assessment of the ecological state of aquatic systems is often only temporary and limited to the present situation. Assessment of historical patterns of change and trend analysis using existing water quality data are required in order 
to gain a balanced overview of how a river has been influenced, particularly in relation to land use.

The Sava River Basin (SRB) is an excellent area on which to investigate both natural and anthropogenic inputs influencing nutrient dynamics in a riverine ecosystem. Our studies have shown that upper reaches are largely regulated by natural processes, middle reaches by agricultural activity and biological processes related to eutrophication, while lower reaches are influenced mainly by stressors related to high pollution from industrial processing, along with untreated municipal waste water discharges (Markovics et al. 2010). Agricultural and industrial sources contribute significantly to the increase in $\mathrm{Na}^{+}, \mathrm{K}^{+}, \mathrm{Cl}^{-}, \mathrm{SO}_{4}{ }^{2-}$, and $\mathrm{NO}_{3}{ }^{-}$concentrations in stream waters. Nitrate inputs are controlled by land use, and the high isotope composition of nitrate at some sites is attributed to sewage and/or animal waste (Ogrinc et al. 2008a, 2015). It was also found that the low discharges, higher temperature, and nutrient enrichment observed in autumn promoted the eutrophication of a river in agricultural areas (Ogrinc et al. 2008a; Markovics et al. 2010). However, the rate of change has not been assessed, and it is important to know this information so that remedial efforts can be targeted and be effective.

We present the first comprehensive evaluation of the longterm water quality data in terms of major nutrient concentrations (N and P) in the SRB at selected locations in Slovenia, Croatia, and Serbia. Annual seasonal variations and the influence of river discharge on nutrient concentrations have been investigated, and temporal trends assessed using trend analysis.

\section{Materials and methods}

\subsection{Site selection}

The Sava River is located in southeast Europe and is a tributary of the Danube River, joining at Belgrade (Fig. 1). It is 990-km long, with a catchment area of $97,713 \mathrm{~km}^{2}$. It flows through four countries: Slovenia, Croatia, Bosnia and Herzegovina, and Serbia. It drains a significant portion of the Dinaric Alps region, via the tributaries of Krka, Kupa, Una, Vrbas, Bosna, and Drina.

The SRB is divided into three climatic areas Alpine, Pannonian, and Continental. Mean annual precipitation and temperature differ over the length of the river. In the upper reaches (alpine headwaters), mean annual precipitation is in the range of 2000-3000 $\mathrm{mm} \mathrm{yr}^{-1}$ with a mean annual temperature of approximately $6{ }^{\circ} \mathrm{C}$. At the confluence of the Sava with the Danube, annual precipitation is $<660 \mathrm{~mm} \mathrm{yr}^{-1}$, and mean annual temperatures are higher at about $13{ }^{\circ} \mathrm{C}$. In general, the discharge of the Sava is greatest in the winter and lowest in the summer. However, seasonal and annual discharges vary by location. The long-term average discharges are 84,255 , and $1722 \mathrm{~m}^{3} \mathrm{~s}^{-1}$ in Ljubljana, Zagreb, and Belgrade, respectively. These values correspond to similar area-normalized discharge values of $17.4,20.5$, and $18.01 \mathrm{~km}^{-2} \mathrm{~s}^{-1}$. The mean residence time of stream water is similar at all sampling points, with a mean value of 1.32 years, generally characterized as being relatively short, indicating that the catchments have relatively low groundwater storage capacity (Ogrinc et al. 2008b).

Land use of the SRB is diverse and complex, reflecting the differences in relief, climate, and stream flow. The greatest population density occurs near the large cities, while agriculture is the dominant activity in the Croatian and Serbian part of the watershed. The upper part of the SRB (in Slovenia) is covered mainly by forests $(>50 \%)$ with subalpine vegetation occupying $\sim 35 \%$. In Croatia, forests cover $25 \%$ and agriculture $>40 \%$ of the basin area. The Bosnian part of the SRB has valleys and hills with about $30 \%$ agriculture and $20 \%$ forest. The majority of the watershed area in Serbia is used for agriculture. Other anthropogenic impacts in the watershed comprise thermo- and hydroelectric plants, oil and gas refinery stations with pipelines, metallurgical, chemical and textile industries, and mining.

Data on water quality were evaluated at eight selected monitoring stations listed in Table 1 and displayed in Fig. 1. These stations were selected on the basis of availability of flow and water quality data and our previous research experience. Three locations were selected in Slovenia (Otoče, Šentjakob, and Jesenice na Dolenjskem) and four in Croatia (Zagreb, Črnac, Slavonski Brod, and Županja). Two locations in Serbia-Sremska Mitrovica and Šabac (location 8)-were treated together, since the data complement each other. Otoče (location 1) is a predominantly forested area and was treated as a background site as it had the lowest observed nutrient concentrations (Table 1). $\delta^{15} \mathrm{~N}_{\mathrm{NO} 3}$ is $<6 \%$ indicating the presence of natural soil-derived nitrogen (Ogrinc et al. 2008a). Šentjakob (location 2) and Zagreb (location 4) are influenced by large cities Ljubljana and Zagreb. Jesenice na Dolenjskem (location 3) is located amid nuclear and hydroelectric plants, while Črnac (location 5), Slavonski Brod (location 6), Županja (location 7), Sremska Mitrovica, and Šabac (location 8 ) are locations highly impacted by agricultural activities (Table 1). In addition, the highest $\delta^{15} \mathrm{~N}_{\mathrm{NO}}$ values (+ $24.4 \%$ ) were observed at Šabac during our study in autumn 2006 when flow was low indicating the influence of animal waste and/or poorly treated sewage (Ogrinc et al. 2008a).

Daily averaged flow rates $\left(\mathrm{m}^{3} \mathrm{~s}^{-1}\right)$ and water quality data (usually monthly) were provided by the Environmental Agency of the Republic of Slovenia (ARSO; URL: http:// www.arso.gov.si/), Hrvatske vode (URL: http://www.voda. hr) and Republic Hydrometeorological Service of Serbia (http://www.hidmet.gov.rs). The analysis covers periods from 2006 to 2012, 2003 to 2012, and 1989 to 2012 in 


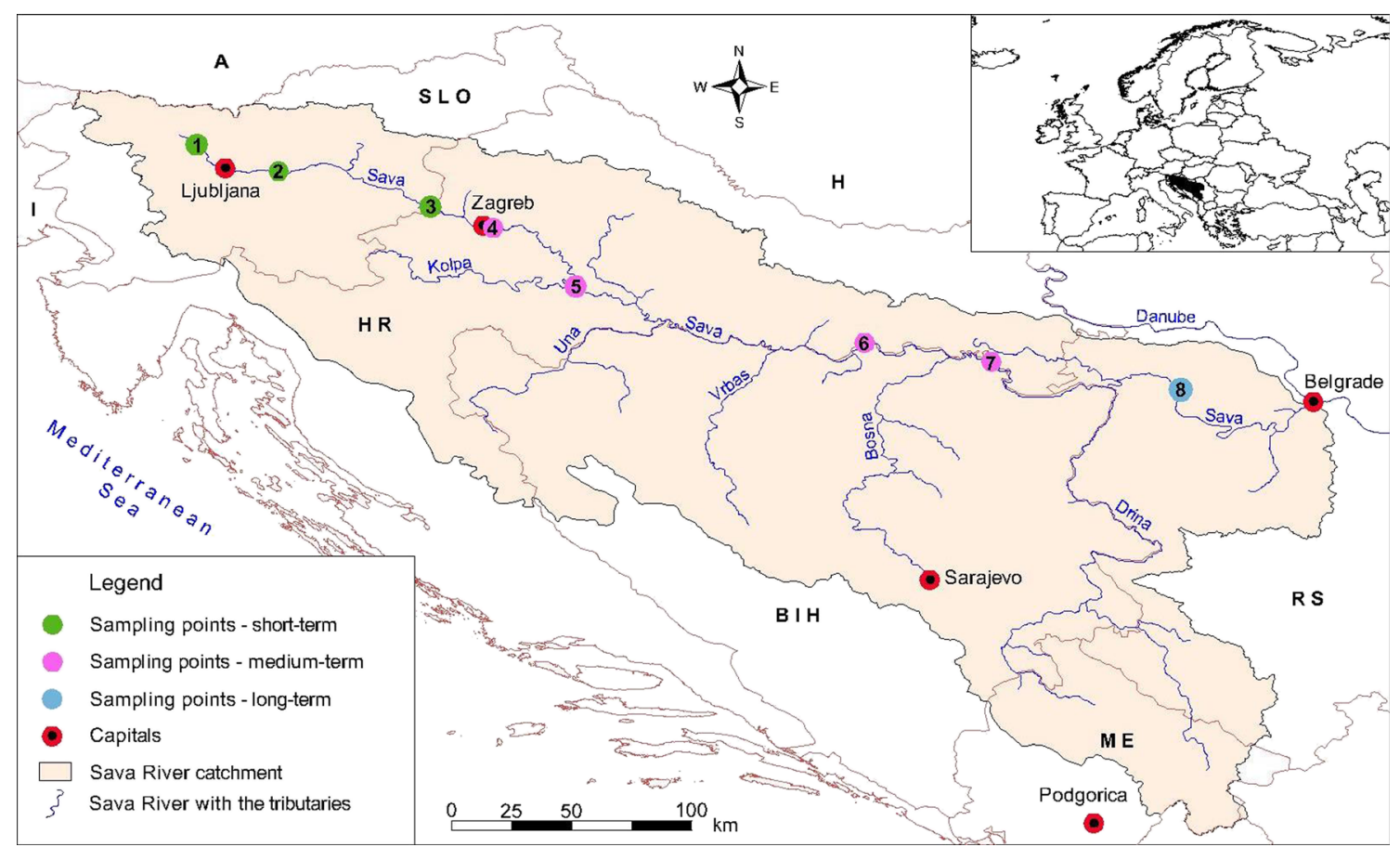

Fig. 1 Map of the selected monitoring locations in the Sava River Basin. These are the following: 1 Otoče, 2 Šentjakob, 3 Jesenice na Dolenjskem, 4 Zagreb, 5 Črnac, 6 Slavonski Brod, 7 Županja, and 8 Sremska Mitrovica and Šabac

Slovenia, Croatia, and Serbia, respectively. Standardized protocols have been used for water sampling and laboratory analysis to obtain comparable monitoring results.

\subsection{Statistical analysis}

Statistical evaluation of the data was performed using Statistica version 7.0 (Statsoft, Tulsa, USA). Normally distributed data were analyzed by ANOVA to test for the temporal and spatial differences in flow and water quality parameters.

The model proposed by Hirsch et al. (2010) was used to estimate concentrations for the entire recorded period. The model considers concentration to be a product of three deterministic components (trend, season, and discharge) and one random component described by the following equation:

$\ln (c)=\beta_{0}+\beta_{1} t+\beta_{2} \ln (Q)+\beta_{3} \sin (2 \pi t)+\beta_{4} \cos (2 \pi t)+\varepsilon$

where $c$ is the concentration $\left(\mathrm{mg} \mathrm{l}^{-1}\right), Q$ is discharge $\left(\mathrm{m}^{3} \mathrm{~s}^{-1}\right), t$ is the time (years), $\varepsilon$ is the unexplained variations, and $\beta_{0-4}$ are fitted coefficients.

Trend analysis at selected locations was performed using linear regressions. This involved first regressing logtransformed concentration data with log-transformed flow

Table 1 Selected monitoring locations with short, medium, and long-term data collection with their distances from the source, height above sea level, and cumulative land use

\begin{tabular}{|c|c|c|c|c|c|c|c|c|c|c|}
\hline $\begin{array}{l}\text { Location } \\
\text { number }\end{array}$ & Sampling location & Country & $\begin{array}{l}\text { Latitude } \\
\mathrm{N}\end{array}$ & $\begin{array}{l}\text { Longitude } \\
\text { E }\end{array}$ & $\begin{array}{l}\text { Distance from } \\
\text { the source }(\mathrm{km})\end{array}$ & $\begin{array}{l}\text { Height above } \\
\text { sea level }(\mathrm{m})\end{array}$ & $\begin{array}{l}\text { Forest } \\
(\%)\end{array}$ & $\begin{array}{l}\text { Agriculture } \\
(\%)\end{array}$ & $\begin{array}{l}\text { Urban and } \\
\text { industry (\%) }\end{array}$ & $\begin{array}{l}\text { Other } \\
(\%)\end{array}$ \\
\hline 1 & Otoče & Slovenia & $46^{\circ} 18^{\prime}$ & $14^{\circ} 14^{\prime}$ & 40 & 415 & 0.9 & 0.1 & 0.01 & 0.004 \\
\hline 2 & Šentjakob & Slovenia & $46^{\circ} 06^{\prime}$ & $14^{\circ} 47^{\prime}$ & 115 & 245 & 3.8 & 1.4 & 0.2 & 0.038 \\
\hline 3 & Jesenice na Dolenjskem & Slovenia & $45^{\circ} 51^{\prime}$ & $15^{\circ} 41^{\prime}$ & 213 & 140 & 6.0 & 2.8 & 0.3 & 0.056 \\
\hline 4 & Zagreb & Croatia & $45^{\circ} 41^{\prime}$ & $16^{\circ} 14^{\prime}$ & 268 & 100 & 7.9 & 4.7 & 0.4 & 0.069 \\
\hline 5 & Črnac & Croatia & $45^{\circ} 25^{\prime}$ & $16^{\circ} 28^{\prime}$ & 376 & 95 & 9.8 & 7.9 & 0.7 & 0.110 \\
\hline 6 & Slavonski Brod & Croatia & $45^{\circ} 09^{\prime}$ & $18^{\circ} 00^{\prime}$ & 564 & 82 & 28.5 & 22.0 & 1.2 & 0.405 \\
\hline 7 & Županja & Croatia & $45^{\circ} 04^{\prime}$ & $18^{\circ} 41^{\prime}$ & 685 & 81 & 36.3 & 28.0 & 1.6 & 0.485 \\
\hline \multirow[t]{2}{*}{8} & Sremska Mitrovica & Serbia & $44^{\circ} 58^{\prime}$ & $19^{\circ} 35^{\prime}$ & 804 & 74 & 52.3 & 36.6 & 2.0 & 0.653 \\
\hline & Šabac & Serbia & $44^{\circ} 44^{\prime}$ & $19^{\circ} 44^{\prime}$ & 837 & 73 & 52.6 & 37.8 & 2.1 & 0.671 \\
\hline
\end{tabular}


data, taking the residual scores from this regression and then regressing them with time (Jones and Armstrong 2001). This procedure minimizes the influence of the correlation between concentration and flow. Trends were considered significant if $p<0.05$. The Shapiro-Wilcox W test was used to test whether the regression residuals were normally distributed.

\section{Results and discussion}

\subsection{Temporal and spatial variations}

The temporal and spatial variations were related to the obtained data and divided into three stages:

- Long-term evaluation of the data (from 1989 to 2012) at location 8;

- Medium-term evaluation of the data (from 2003 to 2012) at locations 4 to 8 ; and

- Short-term evaluation of the data (from 2006 to 2012) from all locations.

Annual flows varied considerably at each location. At location 8 , where a long-term record of flow exists, the lowest mean annual flow was observed in 1990, but for all those stations where a short-term record exists, the lowest mean annual flow was observed in 2011. The highest mean annual flow was observed in 2010 at all locations. Concentrations of the two nutrients $\mathrm{N}$ and $\mathrm{P}$ were correlated significantly with flow at all locations except at location 8. Negative slopes, signifying a dilution effect, were observed at locations 1,2 , 3,4 , and 6 . At locations 5 and 7, a positive correlation between $\mathrm{NO}_{3}{ }^{-}$concentrations and flow was recorded indicating a continuous input of $\mathrm{NO}_{3}{ }^{-}$into the riverine system. Variations in rainfall and temperature were found to contribute greatly to the monthly variation in $\mathrm{NO}_{3}{ }^{-}$concentration.

The data from location 8 covered the period from 1989 to 2012, where the greatest changes in $\mathrm{NO}_{3}{ }^{-}$concentrations were observed after 1989. These changes could be related to several factors associated with the political and economic situations in Serbia. Due to the former, a large percentage of productive farms were abandoned, while industrial activity decreased. Furthermore, statutory regulation of the price of artificial fertilizers declined such that they became more expensive, resulting in a decline in their application. In addition to these socioeconomic factors, two major EU directives controlling nutrient losses to waters were implemented: the Nitrates Directive and the Urban Waste Water Treatment Directive.

Spatial variations in nutrient concentrations were treated statistically for two periods: locations from 4 to 8 were compared for the period from 2003 to 2012, and all locations were compared for the period 2006 to 2012. Significant differences in nutrient concentrations (ANOVA, $p<0.05$ ) were observed between locations 4 to 8 over the last 10 years. Values for locations 4 and 5 differed significantly from those at locations 6,7 , and 8; higher values were observed at locations 4 and 5


$\mathrm{PO}_{4}{ }^{3-}$ concentrations differed at all locations, such as the highest mean concentration of $0.094 \pm 0.077 \mathrm{mg} \mathrm{P}^{-1}$ was observed at location 5 . Statistically significant spatial differences were also observed when short-term data were compared. Values of mean annual $\mathrm{NO}_{3}{ }^{-}$and $\mathrm{PO}_{4}{ }^{3-}$ concentrations differed significantly between all locations for both nutrients (ANOVA, $p<0.05$ ), except for $\mathrm{NO}_{3}{ }^{-}$concentrations, which are similar at locations 3 and 4 and at locations 6 and 7. As expected, the lowest values were at location 1 with average values of $0.70 \pm 0.12 \mathrm{mg} \mathrm{N}^{-1}$ and $0.01 \pm 0.01 \mathrm{mg} \mathrm{P}^{-1}$. The average $\mathrm{NO}_{3}{ }^{-}$concentrations at other locations ranged from $1.00 \pm 0.46$ to $1.64 \pm 0.41 \mathrm{mg} \mathrm{N}^{-1}$ with the lowest concentration observed at location 8 and the highest observed at location 2. Location 2 is close to Ljubljana city where exchange between surface water and groundwater is high. Agriculture is the main source of nitrate pollution in this area, but the discharges from urban areas with no or unregulated sewage systems could also contribute to the lower groundwater quality. The average nitrate concentrations in the Ljubljansko polje groundwater are not of immediate serious concern, but the groundwater quality can only be kept at the same level or improved if appropriate remedial measures are taken immediately (Jamnik and Urbanc 2000). The average $\mathrm{PO}_{4}{ }^{3-}$ concentrations ranged from $0.03 \pm 0.03$ to $0.063 \pm 0.037 \mathrm{mg} \mathrm{P}^{-1}$, with the lowest observed at location 3 and the highest observed at location 5 , which is influenced by intensive agricultural activities.

In addition to changes from year to year, there were clear seasonal fluctuations in nutrient concentrations. Seasonal changes were statistically evaluated for each location separately. Seasonal changes in nutrient concentrations are illustrated using data for locations 5 and 8 as examples (Fig. 2). Statistically significant seasonal variations in $\mathrm{NO}_{3}{ }^{-}$concentrations (ANOVA, $p<0.05$ ) were observed for all locations, except location 2. Values were consistently higher in winter/ autumn months than in spring/summer. The timing of this maximum reflects factors such as leaching of nitrate (which accumulates in the soil in summer and autumn), the high rates of soil water movement in the winter months, and the absence of nitrogen uptake by plants due to low temperatures in the winter period. In contrast, diminished soil water movement and increased plant uptake of nitrogen during low flow conditions causes $\mathrm{NO}_{3}{ }^{-}$concentrations to decrease to a minimum in July and August. Denitrification is not present since hypoxic/anoxic conditions are usually not present in the system. Concentrations of dissolved oxygen (DO) ranged from 6.07 to $18.9 \mathrm{mg}^{-1}$. The study performed in late summer 2006 indicates that reductive conditions were present at locations 5 , 6, and 7 at low flows and high temperatures (Ogrinc et al. 2008a). The concentration of oxygen was also low 
Fig. 2 Boxplots of $\mathrm{NO}_{3}{ }^{-}$and $\mathrm{PO}_{4}{ }^{3-}$ concentrations grouped by month at locations 5 and 8 during the observation period
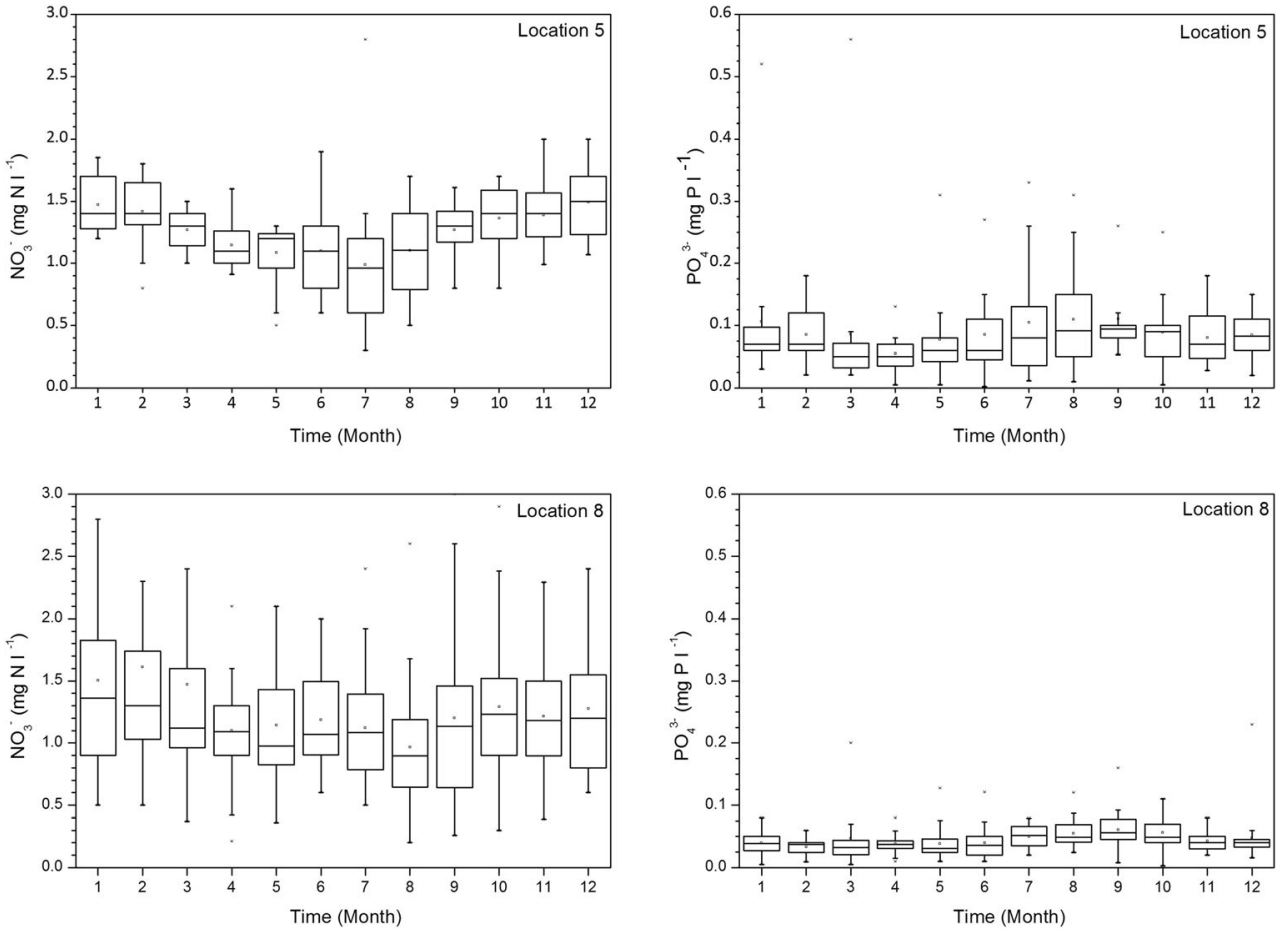

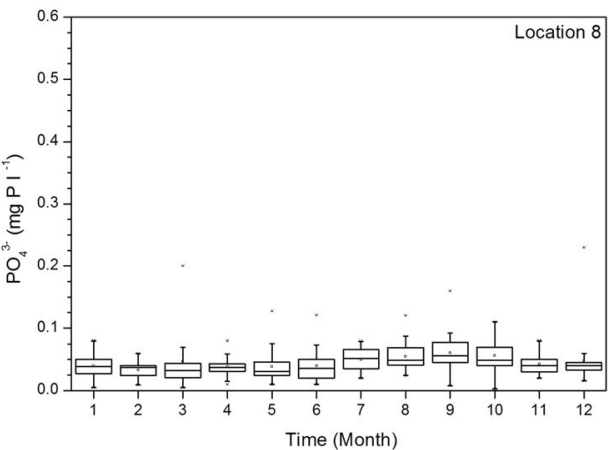

(5.5 $\mathrm{mg} \mathrm{l}^{-1}$ ), which was below the minimum state standard DO concentration of $6 \mathrm{mg} \mathrm{l}^{-1}$. These conditions occurred as a consequence of nutrient enrichment and were confirmed by the presence of the diatom algae Stephanodiscus hantzschii. These algae are usually present in eutrophic environments, and their dynamics are also influenced by temperature and silica content (Jung et al. 2009). The reductive conditions were further indicated by the presence of framboidal pyrite on suspended particulate material (Ogrinc and Ščančar 2013).

No statistically significant temporal differences were observed in $\mathrm{PO}_{4}{ }^{3-}$ concentrations at locations $1,2,3,4$, and 5 . On the other hand, the differences at locations 6 and 8 were statistically significant, with the highest values observed in summer. The higher concentrations could be related to the lower flow conditions observed during the summer and the presence of reductive conditions that could release inorganic $\mathrm{P}$ from sediments into the water column (Billen et al. 2007). At both of these locations, there were higher concentrations of $\mathrm{P}$ in sediments $\left(860 \pm 25 \mathrm{mg} \mathrm{kg}^{-1}\right.$ and $930 \pm 30 \mathrm{mg} \mathrm{kg}^{-1}$, respectively) compared to other locations (Milačič et al. 2009).

\subsection{Trend analysis in water quality}

The results of the trend analysis for nitrate and phosphate are presented in Table 2. The results of the trend analysis performed on $\mathrm{NO}_{3}{ }^{-}$concentrations show that there was a significant trend of decreasing levels, except for location 5 where $\mathrm{NO}_{3}{ }^{-}$concentrations exhibited no significant trend over the reporting period ( $p=0.77942)$. The reduction in $\mathrm{NO}_{3}{ }^{-}$concentrations ranged from 6 to $58 \%$, with the highest being observed at location 2 from 2006 to 2011 and the lowest at location 7 from 2003 to 2011. The trend in $\mathrm{PO}_{4}{ }^{3-}$ concentrations exhibits different behavior. No significant trend was observed at location 1, which is located in a predominantly forested area, suggesting that most of the $\mathrm{PO}_{4}{ }^{3-}$ is of natural origin. Furthermore, no significant trend was observed at locations 2 and 8 . Trends at locations 3 to 6 show significant declines in $\mathrm{PO}_{4}{ }^{3-}$ concentrations of $18-34 \%$. Trend data from rivers in other European countries have shown that about $30 \%$ of the monitoring stations show a decreasing trend and $10 \%$ an increasing trend in nutrient concentrations (both N and P) during the period 1991-2005 (Kronvang et al. 2008; Bouraoui and Grizzetti 2011).

Although there was no significant trend in $\mathrm{PO}_{4}{ }^{3-}$ concentrations at location $8(p=0.32283)$, the switch from a negative slope in the regression line for location 6 to a positive slope for location 8 suggests that inputs of $\mathrm{PO}_{4}{ }^{3-}$ had been increasing downstream. This is possible given that location 8 has been more susceptible to nutrient inputs, mainly from wastewater effluent discharges. This assumption was further supported by our previous investigation conducted in 2006 (Ogrinc et al. 2008a). At this location and in the Sava River near Belgrade, elevated $\delta^{15} \mathrm{~N}_{\mathrm{NO} 3}$ values of up to $+25.5 \%$ fall within the range of animal waste and sewage (Aravena et al. 1993; Fogg et al. 1998; McClelland and Valiela 1998; Wankel et al. 2006), and were only found in autumn 2006. During the high discharge in spring $2006, \delta^{15} \mathrm{~N}_{\mathrm{NO} 3}$ values of $7 \%$ did not show such a predominance of sewage-derived N. Previous studies have indicated that point sources could be relatively important at low flows when the contribution from diffuse catchment sources is lower (Bowes et al. 2005; Arnscheidt et al. 2007). 
Table 2 Statistical results for linear regression (trend analysis) together with the minimum, maximum, and mean $\mathrm{NO}_{3}{ }^{-}$and $\mathrm{PO}_{4}{ }^{3-}$ concentrations

\begin{tabular}{|c|c|c|c|c|c|c|}
\hline \multirow[t]{2}{*}{ No. of location } & \multicolumn{6}{|l|}{$\mathrm{NO}_{3}{ }^{-}$concentrations } \\
\hline & Slope & Mean (mg N ${ }^{-1}$ ) & $\operatorname{Min}\left(\operatorname{mg~N~1}{ }^{-1}\right)$ & $\operatorname{Max}\left(\operatorname{mg~N~~^{-1})}\right.$ & $R^{2}$ & $p$ \\
\hline 1 & $-3.630 \mathrm{E}-5 \pm 1.399 \mathrm{E}-5$ & $0.704 \pm 0.116$ & 0.535 & 1.00 & 0.1752 & 0.0153 \\
\hline 2 & $-7.945 \mathrm{E}-5 \pm 1.141 \mathrm{E}-5$ & $1.640 \pm 0.412$ & 0.967 & 2.69 & 0.5829 & $<0.001$ \\
\hline 3 & $-4.519 \mathrm{E}-5 \pm 8.289 \mathrm{E}-6$ & $1.453 \pm 0.308$ & 0.587 & 2.69 & 0.1390 & $<0.001$ \\
\hline 4 & $-3.691 \mathrm{E}-5 \pm 6.033 \mathrm{E}-6$ & $1.512 \pm 0.359$ & 0.60 & 3.30 & 0.1503 & $<0.001$ \\
\hline 5 & $-2.294 \mathrm{E}-6 \pm 8.181 \mathrm{E}-6$ & $1.250 \pm 0.332$ & 0.30 & 2.80 & -0.004 & 0.7794 \\
\hline 6 & $-3.855 \mathrm{E}-5 \pm 9.140 \mathrm{E}-6$ & $1.075 \pm 0.323$ & 0.30 & 2.60 & 0.0898 & $<0.001$ \\
\hline 7 & $-2.858 \mathrm{E}-5 \pm 6.906 \mathrm{E}-5$ & $1.137 \pm 0.342$ & 0.10 & 2.30 & 0.0593 & $<0.001$ \\
\hline \multirow[t]{3}{*}{8} & $-4.668 \mathrm{E}-6 \pm 5.239 \mathrm{E}-6$ & $1.171 \pm 0.590$ & 0.05 & 5.20 & 0.2575 & $<0.001$ \\
\hline & $\mathrm{PO}_{4}{ }^{3-}$ concentrations & & & & & \\
\hline & Slope & Mean (mg P $\left.1^{-1}\right)$ & $\operatorname{Min}\left(\operatorname{mg~P} 1^{-1}\right)$ & $\operatorname{Max}\left(\operatorname{mg~P} 1^{-1}\right)$ & $R^{2}$ & $p$ \\
\hline 1 & $-5.854 \mathrm{E}-5 \pm 4.015 \mathrm{E}-5$ & $0.009 \pm 0.006$ & 0.0033 & 0.033 & 0.0431 & 0.15778 \\
\hline 2 & $-5.879 \mathrm{E}-5 \pm 5.490 \mathrm{E}-5$ & $0.038 \pm 0.028$ & 0.0059 & 0.112 & 0.00471 & 0.29281 \\
\hline 3 & $-1.457 \mathrm{E}-4 \pm 1.798 \mathrm{E}-5$ & $0.034 \pm 0.031$ & 0.0049 & 0.175 & 0.26534 & $<0.001$ \\
\hline 4 & $-1.231 \mathrm{E}-4 \pm 1.473 \mathrm{E}-5$ & $0.071 \pm 0.053$ & 0.005 & 0.35 & 0.25022 & $<0.001$ \\
\hline 5 & $-1.213 \mathrm{E}-4 \pm 1.158 \mathrm{E}-5$ & $0.090 \pm 0.075$ & 0.002 & 0.56 & 0.34428 & $<0.001$ \\
\hline 6 & $-7.116 \mathrm{E}-5 \pm 1.125 \mathrm{E}-5$ & $0.066 \pm 0.034$ & 0.01 & 0.20 & 0.18584 & $<0.001$ \\
\hline 7 & - & - & - & - & - & - \\
\hline 8 & $8.530 \mathrm{E}-6 \pm 8.605 \mathrm{E}-6$ & $0.050 \pm 0.033$ & 0.003 & 0.25 & $-9.402 \mathrm{E}-5$ & 0.32283 \\
\hline
\end{tabular}

Trend analysis were performed for the period 1989-2012 at location 8, 2003-2012 at locations 4-7 and 2006-2012 at locations 1-3

It is known that point sources are the main source of nutrients in the SRB, constituting $54 \%$ of the total $\mathrm{N}$ and $\mathrm{P}$ loads (ISRBC 2013). For N pollution, the input from agriculture (manure, fertilizers) is an important source with a contribution of $36.1 \%$ of the total emission. For P, input from urban settlements is the most important source with a contribution of $63.5 \%$ of the total emission. Nutrient input via atmospheric deposition as a pathway is $<1 \%$ of the total emission for both $\mathrm{N}$ and $\mathrm{P}$ (ISRBC 2013). In the SRB, there are either no or poorly performing urban wastewater treatment plants (UWWTP). The best wastewater collecting systems are in Slovenia, while in Serbia, $68 \%$ of urban areas have no infrastructure for providing wastewater treatment services (ISRBC 2013). In addition, as of 2007, processes for nutrient removal at UWWTPs were implemented only in Slovenia (ISRBC 2013).

Many industrial facilities are also sources of nutrient pollution. Over the past two decades, the political and economic situation has caused changes in industrial activity in the SRB countries. This process has influenced the generated pollution load and the discharges of industrial wastewater, of which the chemical sector and intensive livestock production are the most important contributors. In 2007 , it was identified that $40 \%$ of industrial waste is discharged directly into surface water ecosystems, from which $71 \%$ of industrial wastewater is discharged without treatment (ISRBC 2013).
Since the SRB belongs to the Danube watershed, the criteria established for sensitive areas have to be respected. The implementation of the Urban Wastewater Treatment Directives (UWWTD; Directive 91/271/EC) in the EU Member States and the development of wastewater infrastructure in non-EU countries are the most important measures to reduce nutrient pollution in SRB by 2015 and beyond. The transition period in Slovenia for implementation of UWWTD ends in 2017, and the results of the Croatian accession negotiation process with deadlines until 2023 were taken into consideration. At present, extensive improvements in urban wastewater treatment are being implemented throughout the basin, and the overall application of nutrient removal technologies is expanding. Based on the pollution reduction scenarios, the final effect of $\mathrm{N}$ and $\mathrm{P}$ reduction in 2015 relative to the year 2007 was estimated to be 55.1 and $61.2 \%$, respectively (ISRBC 2013). However, it must be pointed out that even if the nutrient management is successful, the results of other studies have indicated that at least 4 years will be required to detect any change (Stow et al. 2001; Kronvang et al. 2005; Bouraoui and Grizzetti 2011).

\section{Conclusions}

Comparison of results of nutrient concentrations at selected locations suggests that there is significant temporal and spatial 
variability within the system. Spatial variability in the medium-term data showed that significantly higher annual mean concentrations of $\mathrm{NO}_{3}{ }^{-}$and $\mathrm{PO}_{4}{ }^{3-}$ occurred in Croatia and Serbia at locations influenced by intensive agricultural activity. The temporal variability in nutrient concentrations is controlled by riverine flow, with the highest $\mathrm{NO}_{3}{ }^{-}$concentrations usually being observed during winter/autumn when leaching from soil was most intensive. The lowest $\mathrm{NO}_{3}{ }^{-}$concentrations, observed during summer, are mainly related to the reduction of $\mathrm{NO}_{3}{ }^{-}$due to phytoplankton uptake. On the other hand, the highest $\mathrm{PO}_{4}{ }^{3-}$ concentrations are related to low flow conditions during the summer and the presence of reducing conditions that release inorganic $\mathrm{P}$ from sediments into the water column.

The results of trend analysis indicated that, at most locations, nutrient concentrations decreased by up to $58 \%$. However, sources have either varied (point vs. diffuse) or are uncertain. Nevertheless, the data suggest point sources, especially UWWTPs, are an important source of nutrients at most locations. Hence, all countries within the SRB should consider nutrient removal technologies during the upgrading of existing, or the construction of new, UWWTPs. This research illustrates the utility of long-term water quality monitoring data to provide the basis for empirical analysis and is thus useful for management-related studies.

Acknowledgments This study was supported financially by the EU 7th Research Project-GLOBAQUA (Managing the effects of multiple stressors on aquatic ecosystem under water scarcity). The research was partially conducted within a PhD study of Janja Vrzel financed by the European Social Fund. We thank the staff of Hrvatske vode and the Republic Hydrometeorological Service of Serbia who helped us obtain the discharge and water quality data. Special thanks are given to Roger $\mathrm{H}$. Pain for linguistic corrections and two anonymous reviewers for their constructive comments that improved the quality of the paper.

Open Access This article is distributed under the terms of the Creative Commons Attribution 4.0 International License (http:// creativecommons.org/licenses/by/4.0/), which permits unrestricted use, distribution, and reproduction in any medium, provided you give appropriate credit to the original author(s) and the source, provide a link to the Creative Commons license, and indicate if changes were made.

\section{References}

Aravena R, Evans ML, Cherry JA (1993) Stable isotopes of oxygen and nitrogen in source identification of nitrate from septic systems. Ground Water 31:180-186

Arnscheidt J, Jordan P, Li S, McCormick S, McFaul R, McGrogan HJ, Neal M, Sims JT (2007) Defining the sources of low-flow phosphorus transfers in complex catchments. Sci Total Environ 382:1-13

Billen G, Garnier J, Némery J, Sebilo M, Sferratore A, Barles S, Benoit P, Benoît M (2007) A long-term view of nutrient transfers through the Seine river continuum. Sci Total Environ 375:80-97

Bouraoui F, Grizzetti B (2011) Long term change of nutrient concentrations of rivers discharging in European seas. Sci Tot Environ 409: 4899-4916
Bowes MJ, Hilton J, Irons GP, Hornby DD (2005) The relative contribution of sewage and diffuse phosphorus sources in the River Avon catchment, southern England: implications for nutrient management. Sci Total Environ 344:67-81

Falkowski P, Scholes RJ, Boyle E, Canadell J, Canfield J, Elser J, Gruber J, Hibbard K, Högberg P, Linder S, Mackenzie FT, Moore B III, Pedersen T, Rosenthal Y, Seitzinger S, Smetacek V, Steffen W (2000) The global carbon cycle: a test of our knowledge of earth as a system. Science 290:291-296. doi:10.2307/3078125

Fogg GE, Rolston DE, Decker DL, Louie DT, Grismer ME (1998) Spatial variation in nitrogen isotope values beneath nitrate contamination sources. Ground Water 36:418-426

Hirsch RM, Douglas L, Moyer L, Archfield A (2010) Weighted regression on time, discharge, and season (WRTDS) with an application to Chesapeake bay river inputs. J Am Wat Res Assoc 46:857-880

ISRBC (2013) Sava River Basin management plan. Background paper no. 3: Significant pressures identified in the Sava River Basin, International Sava River Basin Commission, Zagreb, Croatia, 80 pp

Jamnik B, Urbanc J (2000) Origin and quality of groundwater from Ljubljansko polje. RMZ 47:167-178

Jones G, Armstrong N (2001) Long-term trends in total nitrogen and total phosphorus concentrations in Manitoba streams. Water Quality Management Section, Water Branch, Manitoba Conservation. Manitoba Conservation Report No. 2001-07, Winnipeg, Manitoba, Canada, $154 \mathrm{pp}$

Jung SW, Kwon OY, Lee JH, Han MS (2009) Effects of water temperature and silicate on the winter blooming diatom Stephanodiscus hantzschii (Bacillariophyceae) growing in eutrophic conditions in the Lower Han River, South Korea. J Freshwat Ecol 24:219-226

Kronvang B, Jeppesena E, Conley DJ, Søndergaarda M, Larsen SE, Ovesen NB, Carstensen J (2005) Nutrient pressures and ecological responses to nutrient loading reductions in Danish streams, lakes and coastal waters. J Hydrol 304:274-288

Kronvang B, Andersen HE, Børgesen C, Dalgaard T, Larsen SE, Bøgestrand J, Blicher-Mathiasen G (2008) Effects of policy measure implemented in Denmark on nitrogen pollution of the aquatic environments. Environ Sci Pol 11:144-152

Markovics R, Kanduč T, Szramek K, Golobočanin D, Milačič R, Ogrinc N (2010) Chemical dynamics of the Sava riverine system. J Environ Monit 12:2165-2176

McClelland JW, Valiela I (1998) Linking nitrogen in estuarine producers to land-derived sources. Limnol Oceanogr 43:577-585

Milačič R, Ščančar J, Murko S, Kocman D, Horvat M (2009) A complex investigation of the extent of pollution in sediments of the Sava River. Part 1: selected elements. Environ Monit Assess 163:263275. doi:10.1007/s10661-009-0832-x

Ogrinc N, Ščančar J (2013) Suspended particulate matter and water quality of the Sava River Basin. River Syst 20:197-211

Ogrinc N, Markovics R, Kanduč T, Walter LM, Hamilton SK (2008a) Sources and transport of carbon and nitrogen in the River Sava watershed, a major tributary of the River Danube. Appl Geochem 23:3685-3698

Ogrinc N, Kanduč T, Stichler W, Vreča P (2008b) Spatial and seasonal variations in $\delta^{18} \mathrm{O}$ and $\delta \mathrm{D}$ values in the River Sava in Slovenia. $\mathrm{J}$ Hydrol 359:303-312

Ogrinc N, Kanduč T, Kocman D (2015) Integrated approach to the evaluation of chemical dynamics and anthropogenic pollution sources in the Sava River Basin. In: Milačič R, Ščančar J, Paunović M (eds) The handbook of environmental chemistry vol. 31: the Sava River. Springer, Heidelberg, New York, Dordrecht, London, UK, pp 75-94

Stow CA, Borsuk ME, Stanley DW (2001) Long-term changes in watershed nutrient inputs and riverine exports in the Neuse River, North Carolina. Wat Res 35:1489-1499

Wankel SD, Kendall C, Francis CA, Paytan A (2006) Nitrogen sources and cycling in the San Francisco Bay Estuary: a nitrate dual isotope approach. Limnol Oceanogr 51:1654-1664 